The University of San Francisco

USF Scholarship: a digital repository @ Gleeson Library | Geschke Center

Fall 12-17-2019

\title{
A Literature Review on the Benefits for an Interprofessional Educational Program to Increase Novice Nurse Awareness of Case Management in Heart Failure
}

Emily Trefethen

emilyptrefethen@gmail.com

Follow this and additional works at: https://repository.usfca.edu/dnp_qualifying

Part of the Nursing Commons

\section{Recommended Citation}

Trefethen, Emily, "A Literature Review on the Benefits for an Interprofessional Educational Program to Increase Novice Nurse Awareness of Case Management in Heart Failure" (2019). DNP Qualifying Manuscripts. 27.

https://repository.usfca.edu/dnp_qualifying/27

This Manuscript is brought to you for free and open access by the School of Nursing and Health Professions at USF Scholarship: a digital repository @ Gleeson Library | Geschke Center. It has been accepted for inclusion in DNP Qualifying Manuscripts by an authorized administrator of USF Scholarship: a digital repository @ Gleeson Library I Geschke Center. For more information, please contact repository@usfca.edu. 
A Literature Review on the Benefits for an Interprofessional Educational Program to Increase Novice Nurse Awareness of Case Management in Heart Failure Emily Trefethen University of San Francisco School of Nursing and Health Professions 


\begin{abstract}
Purpose/Objectives: The purpose of this literature review is to examine the potential value for an interprofessional education program to increase novice nurse awareness of case management in heart failure.

Primary Practice Setting: Acute care healthcare settings involving novice nurses.

Findings/Conclusions: Evidence demonstrates that interprofessional collaboration on transitional care interventions for HF patients reduces 30-day readmissions. Implementation of an interprofessional education program for novice nurses can be an effective intervention to decrease readmissions by increasing knowledge of the nurse case manager role and development of interprofessional relationships.

Implications for Case Management Practice: Increased awareness of heart failure case management is important for novice nurses. Understanding the nurse case manager role and early interprofessional collaboration can improve patient health outcomes among the heart failure population. Therefore, an education program to build confidence and strengthen interprofessional partnership in heart failure case management for the novice nurse is warranted. Keywords: case management, education, heart failure, heart failure readmissions, interprofessional collaboration, novice nurse, nurse case manager, transitional care
\end{abstract}


Heart Failure (HF) is a chronic and progressive disease where the heart is unable to deliver an adequate amount of blood that the body requires. It is one of the costliest cardiovascular diseases plaguing public health in the United States (Go et al., 2014). HF is the main reason for hospitalizations in adults and a leading contributor to the rise in healthcare costs. Approximately $25 \%$ of Medicare patients are admitted within 30-day of discharge, with an estimated annual cost of $\$ 37$ billion (American Heart and Stroke Association [AHA \& ASA, 2013]). There are approximately 5.1 million Americans diagnosed with HF, and the prevalence of the disease is expected to grow substantially to $46 \%$ by 2030 (Go et al., 2014). In 2018, HF readmission rates among healthcare organizations (HCO) ranged from $20 \%$ to $24 \%$ (Vizient, Inc., 2019). According to Clarkson, Schaffer, and Clarkson (2017), HF patients who are medically cleared to return home from the hospital are at high risk for readmission and poor clinical outcomes.

To address excessive hospital readmissions, the Centers for Medicare and Medicaid Services (CMS, 2019) initiated the Hospital Readmissions Reduction Program (HRRP) in October 2012. The objective of this value-based program is to reduce Medicare payments to HCOs for excessive HF readmissions (CMS, 2019). This initiative aims to associate the payment with the quality of care delivered by the HCO. HRRP encourages medical centers to enhance interprofessional (IP) communication and disease management efforts to promote patient and family engagement with respect to transitional care services (CMS, 2019).

Case management $(\mathrm{CM})$ is a nursing practice focused on care coordination and assessment of discharge needs for a defined patient population (Gray, White, \& Brooks-Buck, 2013). For care interventions to be effective in improving patient and safety outcomes, understanding the value of the nurse case manager (NCM) role is key. The NCM is a registered 
nurse $(\mathrm{RN})$ who is responsible for the care coordination and discharge planning of individual patients to ensure the delivery of cost-effective care (Leonard \& Miller, 2012). Garcia (2017) found a correlation between the success of transitional care interventions and collaboration with the NCM to effectively attain better health results.

According to Allen, Penn, and Nora (2006), an IP approach is essential to patient care delivery to ensure optimal clinical outcomes. An IP approach involves clinicians from different disciplines with specific knowledge and skills working collaboratively to enhance the well-being of the individual through patient-centered practice (Allen et al., 2006). The IP care team may consist of physicians, nurses, pharmacists, social workers, rehabilitation therapists (i.e. occupational, physical, and speech), and dieticians. Collectively, each healthcare professional will work in partnership with one another, the patient, and the patient's family to secure a safe transitional care plan to reduce hospital readmissions and promote successful recovery at home. Transitional care interventions and discharge planning with an IP approach are considered valuable elements to enhance the health of the HF population.

Collaborative effort among the IP team is important to assure that HF transitional care services are arranged prior to discharge to prevent readmission. As primary members of the IP care team, novice nurses are at the frontlines caring for these high-risk patients. Novice nurses are newly licensed RNs that possess six months or less of clinical nursing experience.

Encouragement and education of CM in HF patients are necessary during the new graduate nurse orientation period. A CM education program would facilitate novice nurses to develop their knowledge base on CM, improve care practice, and strengthen IP partnerships. The purpose of this literature review is to assess the potential value of an IP education program to increase novice nurse awareness of $\mathrm{CM}$ in $\mathrm{HF}$. 


\section{Methods}

\section{Data Sources and Searches}

A literature search was performed to obtain evidence supporting the NCM role and effectiveness of IP collaboration on transitional care interventions to prevent HF readmissions. Current practice for novice nurse education and boundary spanning leadership were also reviewed. The search was limited to complete articles that could be obtained electronically. Cumulative Index of Nursing and Allied Health Literature (CINAHL), Fusion, Science Direct, and PubMed databases were searched for applicable articles published in English from 2000 to 2018. Methodology limitations include a lack of current quantitative research pertaining to novice nurse knowledge of HF CM practice and inpatient NCM care interventions. The following keywords were searched: case management, education, heart failure, heart failure readmissions, interprofessional collaboration, novice nurse, nurse case manager, and transitional care. The search generated 240 articles. Inclusion criteria were applied to narrow the results to include articles centered on HF adult (18 years and older) hospitalization, transitional care interventions aimed at reducing HF readmissions, and IP care. A total of 35 studies were screened by title and abstract (if available). Integrative, qualitative, or quantitative reviews specific to HF admissions, the role of the NCM, IP approach, novice nurse education, and HF transitional care interventions were selected. The remaining 12 articles were analyzed and critically appraised using the Johns Hopkins Nursing EBP Non-Research/Research Appraisal Tool. The final literature collection is summarized in Appendix A.

\section{Evidence}

HCOs strive to provide excellence of care to all patients, with a commitment to improving quality and patient safety practices. According to Driscoll, Tobis, Gurka, Serafin, and 
Carlson (2015), segregation between clinical service lines and patient care units is present in the inpatient setting. Unfortunately, silos present challenges to providing patients the optimal care they require. Healthcare silos emerge when clinical disciplines work exclusively from one another causing barriers to communication and partnership with IP members of the care team. Silos create poor communication and collaboration between disciplines, which compromises the health outcomes of the patients served (Driscoll et al., 2015). Driscoll et al. (2015) reported on an in-house diversion plan on the neuroscience care units at a Midwest academic medical center to better patient flow and safety, while decreasing internal diversions. The plan was created to find admitted patients primary and secondary placement options to support bed flow and patient safety. Interventions, such as forecasting tools and daily bed huddles, proved to decrease internal diversion and improve bed flow. Enhanced collaboration resulted in a $50 \%$ reduction, with inpatients being internally diverted to alternate patient care units. Driscoll et al. (2015) found that the process improvement initiative led to improved collaboration between all organizational members.

Increased communication and collaboration between patient care units and IP teams are possible when healthcare silos are eliminated. Medically complex patients require navigation of care through a fragmented healthcare system. Boundary spanning practices can help with maintaining effective IP collaboration and communication to ensure healthcare silos are avoided. Ehrlich, Kendall, and Muenchberger (2012) performed a qualitative study based on ground theory aimed to gain an understanding of the difference between routine chronic care and chronic care coordination. Ehrlich et al. (2012) interviewed 10 general practitioners and six registered nurses (RNs) from an Australian community-based setting who provided complex care coordination. Four processes emerged to classify CM: (a) moving beyond routine care practice 
by spanning boundaries, (b) relationship-based care, (c) established roles, and (d) commitment to chronic care coordination. These results implied that effective CM depended on the ability to shift across boundaries to achieve optimal clinical outcomes (Ehrlich et al., 2012). Spanning boundaries to efficiently organize care involves IP communication and collaboration. According to Ehrlich et al. (2012), CM education and role clarification need to be explored further. Boundary spanning practice connects the organization and clinical environment together by creating strong relationships among patients and the IP team.

Integration of care coordination into routine care would offer clarification about the CM (Ehrlich et al., 2012). Growing evidence indicates that IP education and collaborative care are essential elements of healthcare education and practice (Institute of Medicine, 2003; World Health Organization, 2010). Confidence is required for effective IP collaboration. In the beginning of novice nurses' clinical careers, they often lack confidence because of their inexperience, which can negatively impact the delivery of safe and effective care (Pfaff et al., 2014). Pfaff et al. (2014) explored new graduate nurse confidence in IP collaboration through an exploratory mixed-methods design, which included 514 new graduate nurses working at acute, community, and long-term care facilities in Ontario, Canada who participated in a cross-sectional descriptive survey. Results were linked to novice nurse development (e.g., experience and knowledge), as well as team (e.g., leadership, respect, and opportunities) and leadership support. Opportunities for new graduate nurses to build relationships with other healthcare disciplines and to discover more about their roles and shared governance improved IP collaboration. Participation at IP rounds and CM meetings allowed new graduate nurses opportunities for valuable collaboration (Pfaff et al., 2014). In addition, increased confidence of new graduate 
nurses was achieved through knowing other disciplines, their functions, and how and when to collaborate with each other (Pfaff et al., 2014).

Nurse engagement is imperative for respectable and trustworthy IP collaboration. An integrative review conducted by Pfaff, Baxter, Jack, and Ploeg (2013) examined barriers that new graduate nurses encountered in IP collaboration. Twenty-six articles were selected and appraised. The analysis illustrated that new graduate nurse engagement barriers to IP collaboration included individual factors (i.e., lack of self-confidence, knowledge, experience, and communication), team factors, and leadership factors. Despite a mediocre collection sample, the review suggested implications for team and organizational development, education, and research that may influence new graduate nurse engagement in IP collaboration (Pfaff et al., 2013).

Achieving the highest clinical outcomes for the HF population is a primary goal of the clinical team. Clarkson et al. (2016) evaluated the impact of an HF education-based program on hospital readmissions. The project aim was intended to understand the relationship between attendance of an outpatient HF education program and 30-day readmissions. A total of $106 \mathrm{HF}$ patients with a New York Heart Association classification of II or III participated by attending an IP outpatient education program at no charge. Heart Failure University (HFU) offered HF patients with comprehensive education on their disease process and management. Results afforded a statistically significant relationship between 30-day readmission and HFU attendance $\left(\chi^{2}[1, N=106]=5.68, p=.02\right)$. Findings supported the effectiveness of HFU attendance in reducing 30-day readmissions, compared to HF patients who did not receive the intervention. Results validate the evidence of IP educational-based strategies to decrease HF readmissions (Clarkson et al., 2016). 
Heckman et al. (2018) found that care delivered with an IP chronic disease management approach was useful in reducing readmissions. Barriers to HF management observed in the healthcare setting are knowledge gaps and ineffective IP communication. Heckman et al. performed a pilot study to assess impact of an IP educational care-based program to improve HF knowledge, increase IP communication, and enhance workflow processes: Enhancing Knowledge and Interprofessional care for HF (EKWIP-HF). Educational training and resources were provided to clinical staff by HF and/or long-term care (LTC) specialists. IP care teams were created and continued educational support was delivered by HF/LTC expert clinicians until group members were able to confidently execute their roles. The EKWIP-HF program was piloted over six months in a convenience sample of LTC homes in South Central Ontario, Canada. Results were consistent at both settings where optimization of IP communication to promote HF care was established. Improved confidence among staff, enhanced skills, and better IP collaboration were seen (Heckman et al., 2018).

Collaboration between the NCM and novice nurse on discharge planning is crucial to avoid HF readmissions. Early collaboration between the NCM, novice nurse, patient, family, and the IP team is essential to developing a safe discharge plan. Thoma and Waite (2018) studied elements that contributed to an effective partnership between the $\mathrm{NCM}(\mathrm{N}=8)$ and a multidisciplinary team in an acute care international setting through a qualitative descriptive study. Significant themes discovered were professional competency of the NCM as self-valued or valued by peers, shared collaboration between the NCM and patients, and identification of barriers to discharge (Thoma \& Waite, 2018). It is important to emphasize that a successful discharge plan can be acquired through patient and family collaboration to garner desirable health results. 
$\mathrm{CM}$ is a nursing specialty that novice nurses are unfamiliar with, since nursing curricula and orientation programs do not emphasize the discipline (Pfaff et al., 2014). Gray et al. (2013) investigated role ambiguity of the NCM in a qualitative study through a phenomenological method. A convenience sample size of NCM participants $(\mathrm{N}=25)$ confirmed uncertainty of job function regarding the utilization of time, resources, and nursing abilities. For care interventions to be effective in improving patient and safety outcomes, understanding the value of the NCM role is key. Gray et al. found a correlation between the success of transitional care interventions and collaboration with the NCM to effectively attain better health effects.

Understanding the value of the NCM's role on the IP care team is important for the novice nurse. The NCM not only coordinates care but is a true advocate for the patient. Hellwig, Yam, and DiGiulio (2003) explored the meaning of advocacy from the NCM's (N=7) perspective through a phenomenological approach in a qualitative study. The NCM's perspective as a patient advocate is to ensure that the individual's health, safety, and rights are protected. Participants challenged NCMs to be the voice for their patients. Establishing a genuine bond with the patient will render the individual to feel safe and valued. The relationship-based connection is safeguarded by trust, resulting in better patient, provider, and health system outcomes (Hellwig et al., 2003).

Innovative research and implementation of evidence-based practice (EBP) has improved health outcomes among HF patients (Riegel et al., 2002). Pharmaceutical therapies, discharge education, and supportive interventions are independent variables that have proven to reduce hospitalizations, while increasing the quality of life among the HF community. Riegel et al. (2002) examined the success of a telephonic CM intervention in HF patients to lower posthospitalization resource use through a random control trial (RCT). The telephonic CM plan 
improved organization goals by lowering hospital readmissions (three months at $45.7 \%, \mathrm{p}=.03$ and six months at $47.8 \%, \mathrm{p}=.01$ ), costs (six months at $45.5 \%, \mathrm{p}=.04$ ), and post discharge resource use. In addition, Riegel et al. observed enhanced patient satisfaction. Findings concluded that the use of telephonic care follow-up in HF patients reduced hospitalizations, costs, and other resource use, while increasing patient satisfaction. The telephonic CM program demonstrated an increase in the overall wellbeing of HF individuals (Riegel et al., 2002).

Establishing a robust discharge plan is crucial to sustaining optimal health outcomes once patients are transitioned from hospital to home. Another RCT study conducted by Riegel, Carlson, Glaser, and Romero (2017) explored the value of telephonic transitional CM in lowering hospital admissions, improving health-related quality of life, and reducing despair in HF Hispanic patients. Results from this study validated that early CM intervention decreased acute care resource use (one month at $8.7 \%, \mathrm{p}=.46$ ). The study implied that telephonic CM improved patient and safety outcomes in HF Hispanic patients (Riegel et al., 2017).

Joo and Huber (2014) provided an integrative review to support that community-based case management $(\mathrm{CBCM})$ is a desirable transitional care intervention. $\mathrm{CBCM}$ centers on care coordination for high-risk patients in the community who require individualized transitional follow-up care and support services for disease management (Joo, 2014). Joo and Huber chose a collection of 18 studies for this review, where all results incorporated the CM intervention of home health services, telephonic follow-up, and patient education. An evidence evaluation table was included to present findings of each study. Results revealed that CBCM decreased readmissions, optimized health outcomes, and increased client gratification (Joo \& Huber, 2014).

Early collaboration between the NCM, novice nurse, patient, family, and the IP team is essential to developing a safe discharge plan. Thoma and Waite (2018) studied elements that 
contribute to an effective partnership between the $\mathrm{NCM}(\mathrm{N}=8)$ and multidisciplinary team in an acute care international setting through a qualitative descriptive study. Significant themes discovered were professional competency of the NCM as self-valued or valued by peers and shared collaboration between NCM and patients, as well as identification of barriers to discharge (Thoma \& Waite, 2018). It is important to emphasize that a successful discharge plan can be acquired through patient, family, and IP collaboration to yield desired health outcomes.

\section{Summary of Evidence}

The articles examined in Appendix A outline essential components that are valuable in an education program for the novice nurse to be successful with increasing their knowledge base of CM. Novice nurses are unfamiliar about the NCM role, responsibilities, and how to engage in collaboration with the NCM since CM is not incorporated into the nursing curricula or unit orientation (Pfaff et al., 2014). Establishing a strong relationship between the NCM and novice nurse on discharge planning is crucial to avoid HF readmissions. Research proved a correlation between the success of transitional care interventions and IP partnership with the NCM to effectively attain better HF patient health outcomes (Garcia, 2017). Collaborative innovations that have the potential to improve the well-being of the community can emerge by crossing boundaries to build relationships. Boundary spanning in healthcare can eliminate silos and bridge IP teams together. The advantages of an IP education program for the novice nurse are to enhance CM knowledge and encourage NCM engagement on transitional care collaboration to prevent HF readmissions. Moreover, the program is expected to enhance the relationship between the IP care team, improve collaboration on discharge planning, and enrich the patient's overall health. 


\section{Analysis}

The integrated review of evidence provides significant insight into the benefits of continued education for the professional development of the novice nurse and their engagement in IP collaboration. Better knowledge and confidence of the novice nurse will promote positive collaboration on the discharge planning of HF patients, which may help reduce readmissions. According to Gilman, Chokshi, Bowen, Rugen, and Cox (2014), reforming IP education care involves enhancing IP awareness, team-based practice, and optimal care delivery. It is imperative to breakdown healthcare silos that impede mutual partnership among team members in order to provide best care practice (Driscoll et al., 2015).

When fragmented care exists between IP disciplines, opportunities for risk, and inefficiencies are present. Spanning boundary leadership practice will facilitate improving communication and collaborative processes between care team members (Shirey \& WhiteWilliams, 2015). Strengthening the knowledge of the novice nurse and IP collaboration as it pertains to the discharge planning process was explored. IP commitment to excellence in care is guided by a multidisciplinary approach through successful transitional care collaboration resulting in positive patient outcomes.

\section{Implications for Case Management Practice}

$\mathrm{CM}$ is a specialized clinical practice designed to coordinate and manage patient care (White \& Hall, 2006). CM is effective for improving the quality of care among HF patients post-hospitalization. Awareness of the NCM role and transitional care process will afford the novice nurse confidence in IP collaboration on meeting the discharge needs of the patient. The implementation of a CM training program to enhance IP collaboration on discharge planning should demonstrate to be useful for the novice nurse. Gaining enhanced knowledge about the 
NCM role and creating strong IP relationships will promote collaboration of effective HF case management interventions by the novice nurse and offer a sense of belonging to the care team.

According to Pfaff et al. (2013), novice nurses can be better prepared for IP practice when nursing curricula or orientation programs address other interdisciplinary roles. IP education is valuable as it provides novice nurses with a voice to positively impact their care practice as dedicated patient advocates. A strong partnership with the IP team will positively affect clinical outcomes for chronically ill patients requiring complex care needs.

Nurse leaders are in key positions to empower novice nurses and influence the development of clinical knowledge. As visionary change models, nurse leaders must promote a culture of opportunity for learning, teamwork, and respect among members. Continued education and encouragement for novice nurses are important to guide their clinical success. Structured support may include various strategies such as engaging novice nurses in $\mathrm{CM}$ education training, meetings, and discharge planning processes, and improving CM awareness, knowledge, skills, and confidence in transitional care collaboration.

\section{Conclusion}

HF readmissions remain a national problem and influence the rise in healthcare expenses among adults. Transitional care interventions and discharge planning with an IP approach are considered valuable factors to improve patient health outcomes. Understanding the importance of the NCM role and early IP collaboration to coordinate transitional care services for HF patients is imperative.

IP care education is a valuable intervention for the novice nurse to expand clinical competence and knowledge. Redesigning IP education for HF to increase awareness of CM in novice nurses was examined. As a new member of the IP care team, novice nurses must 
establish trusted relationships with their patients and successfully collaborate with the care team to excel in practice. Literature analyzed supported the implementation of an IP education program to address the clinical understanding of the NCM and how the reduction of HF readmissions correlates to better health outcomes within the HF population.

The successful transition from novice to an experienced nurse is greatly influenced by team and organizational support. Supportive relationships encourage confidence in IP collaboration and promote opportunities for engagement among other clinical disciplines. The growth of the novice nurse is dependent on a combination of continued education and experience. The legacy of nursing practice is found in our novice nurses and investing in their future is a valued commitment to their advancement. 


\section{References}

Allen, D. D., Penn, M. A., \& Nora, L. M. (2006). Interdisciplinary healthcare education: Fact or fiction? American Journal of Pharmaceutical Education, 70(2):39. doi: 10.5688/aj700239

American Heart Association Statistics Committee and American Stroke Statistics Subcommittee. (2013). Heart disease and stroke statistics-2013 update: a report from the American Heart Association. Circulation, 127(1), e6-e245. doi: 10.1161/CIR.0b0 $13 \mathrm{e} 31828124 \mathrm{ad}$.

Centers for Medicare and Medicaid Services. (2019). Hospital readmissions reduction program (HRRP). Retrieved from https://www.cms.gov/Medicare/MedicareFee-for-Service-Payment/AcuteInpatientPPS/Readmissions-Reduction-Program.html

Clarkson, J. N., Schaffer, S. D., \& Clarkson, J. J. (2016). The effect of an interprofessional heart failure education program on hospital readmissions. Journal for Healthcare Quality, 39(2), 78-84. doi:10.1097/JHQ.0000000000000027

Driscoll, M., Tobis, K., Gurka, D., Serafin, F., \& Carlson, E. (2015). Breaking down the silos to decrease internal diversions and patient flow delays. Nursing Administration Quarterly, 39(1), e1-e8. doi: 10.1097/NAQ.0000000000000080

Ehrlich, C., Kendall, E., \& Muenchberger, H. (2012). Spanning boundaries and creating strong patient relationships to coordinate care are strategies used by experienced chronic condition care coordinators. Contemporary Nurse, 42(1), 67-75. doi:10.5172/conu.2012.42.1.67

Garcia, C. G. (2017). A literature review of heart failure transitional care interventions. The American Journal of Accountable Care, 5(3), 21-25. Retrieved from https://www.ajmc.com/jounals/ajac/2017/2017-vol5-n3/a-literature-review-of-heart- 
failure-transitional-care-interventions

Gilman, S. C., Chokshi, D. A., Bowen, J. L., Rugen, K. W., \& Cox, M. (2014). Connecting the dots: Interprofessional health education and delivery system redesign at the Veterans Health Administration. Academic Medicine, 89(8), 1113-1116. doi: 10.1097/ 0000000000000312

Go, A. S., Mozaffarian, D., Roger, V. L., Benjamin, E. J., Berry, J. D., Blaha, M. J., ... American Heart Association Statistics Committee and Stroke Statistics Subcommittee. (2014). Heart disease and stroke statistics-2014 update: A report from the American Heart Association. Circulation, 129(3), e28-e292. doi: 10.1161/01.cir.0000441139.02102.80

Gray, F. C., White, A., \& Brooks-Buck, J. (2013). Exploring role confusion in nurse case Management. Professional Case Management, 18(2), 66-76. doi: 10.1097/NCM.0b013e31827a4832

Heckman, G. A., Boscart, V. M., Huson, K., Costa, A., Harkness, K., Hirdes, J. P., ... McKelvie, R. S. (2018). Enhancing knowledge and interprofessional care for heart failure (EKWIP-HF) in long-term care: A pilot study. Pilot and Feasibility Studies, 4(9), 1-11. doi: 10.1186/s40814-017-0153-8

Hellwig, S. D., Yam, M., \& DiGiulio, M. (2003). Nurse case managers’ perceptions of advocacy: A phenomenological inquiry. Lippincott's Case Management, 8(2), 53-65. doi: 10.1097/00129234-200303000-00002

Institute of Medicine. (2003). Health professions education: A bridge to quality. Washington, DC: The National Academics Press.

Joo, J. Y. (2014). Community-based case management, hospital utilization, and patient-focused 
Outcomes in medicare beneficiaries. Western Journal of Nursing Research, 36(6), 825-844. doi: 10.1177/0193945913514140.

Joo, J. Y., \& Huber, D. L. (2014). An integrative review of nurse-led community-based case management effectiveness. International Nursing Review, 61(1), 14-24. doi: 10.1111/inr.12068

Leonard, M. \& Miller, E. (2012). Nursing case management review and resource manual $4^{\text {th }}$ ed. Silver Spring, MD: American Nurses Credentialing Center. Retrieved from https://www.nursingworld.org/ 4ae0a9/globalassests/catalog/ sample-chapters/nursingcasemgmt-samplechapter.pdf

Pfaff, K. A., Baxter, P. E., Jack, S. M., \& Ploeg, J. (2013). An integrative review of the factors influencing new graduate nurse engagement in interprofessional collaboration. Journal of Advanced Nursing, 70(1), 4-20. doi: 10.1111/jan.12195

Pfaff, K. A., Baxter, P. E., Jack, S. M., \& Ploeg, J. (2014). Exploring new graduate nurse confidence in interprofessional collaboration: A mixed methods study. International Journal of Nursing Studies. doi: 10.1016/j.ijnurstu.2014.01.001

Riegel, B., Carlson, B., Glaser, D., \& Romero, T. (2017). Randomized controlled trial of telephone case management in Hispanics of Mexican origin with heart failure. Journal of Cardiac Failure, 12(3), 211-219. doi: 10.1016/j.cardfail.2006.01.005

Riegel, B., Carlson, B., Kopp, Z., Lepetri, B., Glaser, D., \& Unger, A. (2002). Effect of a standardized nurse case-management telephone intervention on resource use in patients with chronic heart failure. Archives of Internal Medicine, 162(6), 705-712 doi:10.1001/archinte.162.6.705

Shirey, M. R., \& White-Williams, C. (2015). Boundary spanning leadership practices for 
Population health. Journal of Nursing Administration, 45(9), 411-415. doi: 10.1097/ NNA.0000000000000223

Thoma, J. E., \& Waite, M. A. (2018). Experiences of nurse case managers within a central discharge planning role of collaboration between physicians, patients and other healthcare professionals: A sociocultural qualitative study. Journal of Clinical Nursing, 27(5), 1198-1208. doi: 10.1111/jocn.14166

Vizient Inc. (2019, September 30). Quality assurance scorecard: 2019. Retrieved from https://vizientinc.com

White, P., \& Hall, M. E. (2006). Mapping the literature of case management nursing. Journal of Medical Library Association, 94(2 Supplemental), E99-106.

World Health Organization. (2010). Framework for action on interprofessional education and collaborative practice. Geneva: WHO Press. 


\section{Appendix A. Evidence Table}

\begin{tabular}{|c|c|c|c|c|c|}
\hline Citation and Title & $\begin{array}{l}\text { Purpose of } \\
\text { Study }\end{array}$ & Design/Method & Sample/Setting & Study Findings & $\begin{array}{l}\text { Appraisal } \\
\text { Rating }\end{array}$ \\
\hline $\begin{array}{l}\text { Clarkson et al. } \\
\text { (2016). The effect } \\
\text { of an } \\
\text { interprofessional } \\
\text { heart failure } \\
\text { education program } \\
\text { on heart failure } \\
\text { readmissions. }\end{array}$ & $\begin{array}{l}\text { Assess the } \\
\text { impact of a HF- } \\
\text { education based } \\
\text { program on } \\
\text { hospital } \\
\text { readmissions. }\end{array}$ & $\begin{array}{l}\text { Retrospective } \\
\text { case-control } \\
\text { study design }\end{array}$ & $\begin{array}{l}106 \text { NYHA } \\
\text { function class } \\
\text { II/III HF patients } \\
\text { (53 female and } \\
53 \text { male } \\
\text { participants). } \\
\text { Acute care } \\
\text { hospital in } \\
\text { Northeast FL. }\end{array}$ & $\begin{array}{l}\text { There is a } \\
\text { significant } \\
\text { correlation } \\
\text { among patients } \\
\text { who attended } \\
\text { HFU for } \\
\text { continued } \\
\text { outpatient } \\
\text { education and a } \\
\text { decrease in } \\
\text { readmissions }\left(\chi^{2}\right. \\
{[1, \mathrm{~N}=106]=} \\
5.68, p=.02) .\end{array}$ & $\begin{array}{l}\text { Good } \\
\text { Quality- } \\
\text { Level III }\end{array}$ \\
\hline $\begin{array}{l}\text { Driscoll et al. } \\
(2015) \text {. Breaking } \\
\text { down the silos to } \\
\text { decrease internal } \\
\text { diversions and } \\
\text { patient flow delays. }\end{array}$ & $\begin{array}{l}\text { Effectiveness of } \\
\text { a hospital-wide } \\
\text { diversion plan to } \\
\text { improve } \\
\text { communication } \\
\text { and } \\
\text { collaboration to } \\
\text { decrease internal } \\
\text { diversions. } \\
\end{array}$ & $\begin{array}{l}\text { Quality } \\
\text { improvement, } \\
\text { cyclic method }\end{array}$ & $\begin{array}{l}600 \text { bed } \\
\text { academic, } \\
\text { tertiary care } \\
\text { specialty } \\
\text { hospital. } \\
\text { Neuroscience } \\
\text { service line. }\end{array}$ & $\begin{array}{l}\text { Enhanced IP } \\
\text { collaboration } \\
\text { minimized } \\
\text { internal } \\
\text { diversions and } \\
\text { improved patient } \\
\text { flow while } \\
\text { increasing } \\
\text { patient safety. }\end{array}$ & $\begin{array}{l}\text { Good } \\
\text { Quality- } \\
\text { Level V }\end{array}$ \\
\hline $\begin{array}{l}\text { Ehrlich et al. } \\
(2012) \text {. Spanning } \\
\text { boundaries and } \\
\text { creating } \\
\text { strong patient } \\
\text { relationships to } \\
\text { coordinate care are } \\
\text { strategies used by } \\
\text { experienced } \\
\text { chronic condition } \\
\text { care coordinators. }\end{array}$ & $\begin{array}{l}\text { Gain an } \\
\text { understanding of } \\
\text { the difference } \\
\text { between usual } \\
\text { chronic } \\
\text { condition care } \\
\text { and the work of } \\
\text { chronic } \\
\text { condition care } \\
\text { coordination. }\end{array}$ & $\begin{array}{l}\text { Qualitative, } \\
\text { thematic analysis }\end{array}$ & $\begin{array}{l}\text { Ten general } \\
\text { practitioners and } \\
\text { six RNs }(n=16) \\
\text { that provided } \\
\text { CM to patients } \\
\text { with complex } \\
\text { chronic } \\
\text { conditions in } \\
\text { practicing in an } \\
\text { Australian } \\
\text { healthcare } \\
\text { setting. }\end{array}$ & $\begin{array}{l}\text { Four themes } \\
\text { were identified } \\
\text { to describe the } \\
\text { process of CM } \\
\text { which were: } 1 \text { ) } \\
\text { moving beyond } \\
\text { usual practice by } \\
\text { spanning } \\
\text { boundaries; } 2 \text { ) } \\
\text { relationship- } \\
\text { based care; } 3 \text { ) } \\
\text { agreed roles and } \\
\text { routines among } \\
\text { relevant parties; } \\
\text { and } 4 \text { ) } \\
\text { committing to } \\
\text { chronic } \\
\text { condition CM. }\end{array}$ & $\begin{array}{l}\text { Good } \\
\text { Quality- } \\
\text { Level V }\end{array}$ \\
\hline $\begin{array}{l}\text { Gray et al. (2013). } \\
\text { Exploring role } \\
\text { confusion in nurse } \\
\text { case management. }\end{array}$ & $\begin{array}{l}\text { Identify the } \\
\text { areas where role } \\
\text { confusion and } \\
\text { uncertainty are } \\
\text { present in NCM. }\end{array}$ & $\begin{array}{l}\text { Qualitative, } \\
\text { phenomenology }\end{array}$ & $\begin{array}{l}\text { NCMs }(n=25) \\
\text { practicing in } \\
\text { small East Coast } \\
\text { medical } \\
\text { outpatient } \\
\text { clinics. } \\
\text { Valid RN } \\
\text { license. }\end{array}$ & $\begin{array}{l}\text { NCMs } \\
\text { experienced role } \\
\text { confusion with } \\
\text { time resource, } \\
\text { capabilities, and } \\
\text { various } \\
\text { individual roles. } \\
\text { In addition, } \\
\text { conflict and } \\
\text { misperception } \\
\text { on multi-facet }\end{array}$ & $\begin{array}{l}\text { Good } \\
\text { Quality- } \\
\text { Level III }\end{array}$ \\
\hline
\end{tabular}




\begin{tabular}{|c|c|c|c|c|c|}
\hline & & & & $\begin{array}{l}\text { role and } \\
\text { responsibility of } \\
\text { NCM. }\end{array}$ & \\
\hline $\begin{array}{l}\text { Heckman et al. } \\
\text { (2018). Enhancing } \\
\text { knowledge and } \\
\text { interprofessional } \\
\text { care for heart } \\
\text { failure (EKWIP- } \\
\text { HF) in long-term } \\
\text { care: A pilot study. }\end{array}$ & $\begin{array}{l}\text { Develop a } \\
\text { sustainable and } \\
\text { effective IP HF } \\
\text { care processes in } \\
\text { long term care } \\
\text { (LTC). }\end{array}$ & $\begin{array}{l}\text { Mixed methods } \\
\text { design. }\end{array}$ & $\begin{array}{l}\text { Convenience } \\
\text { sample of two } \\
\text { units of two LTC } \\
\text { facilities in } \\
\text { South Central } \\
\text { Ontario, Canada. }\end{array}$ & $\begin{array}{l}\text { EKWIP-HF was } \\
\text { feasible. HF } \\
\text { knowledge and } \\
\text { IP collaboration } \\
\text { improved. }\end{array}$ & $\begin{array}{l}\text { Good } \\
\text { Quality- } \\
\text { Level IIIb }\end{array}$ \\
\hline $\begin{array}{l}\text { Hellwig et al. } \\
(2003) \text {. Nurse case } \\
\text { managers' } \\
\text { perceptionsof } \\
\text { advocacy: A } \\
\text { phenomenological } \\
\text { inquiry. }\end{array}$ & $\begin{array}{l}\text { Explore the } \\
\text { meaning of } \\
\text { advocacy from } \\
\text { the NCM's } \\
\text { view. }\end{array}$ & $\begin{array}{l}\text { Qualitative, } \\
\text { descriptive, } \\
\text { phenomenology }\end{array}$ & $\begin{array}{l}\text { NCMs }(n=7) \\
\text { from two New } \\
\text { Jersey Hospitals. } \\
\text { Experienced } \\
\text { NCM ( } 2 \text { years or } \\
\text { more in CM). } \\
\text { Inpatient RN } \\
\text { Female CMs } \\
\text { only. } \\
\text { BSN or MSN } \\
\text { graduate. }\end{array}$ & $\begin{array}{l}\text { Patient advocacy } \\
\text { is the focus of } \\
\text { the NCM. Five } \\
\text { categories } \\
\text { emerged to } \\
\text { describe the } \\
\text { meaning of } \\
\text { advocacy from } \\
\text { the NCM's } \\
\text { perspective: 1) } \\
\text { Advocacy } \\
\text { Perspective, 2) } \\
\text { Taking Care of } \\
\text { Business, 3) } \\
\text { Being a Veteran, } \\
\text { 4) Barriers and } \\
\text { Facilitators, and } \\
\text { 5) Feelings } \\
\text { Related to the } \\
\text { Work of } \\
\text { Advocacy. }\end{array}$ & $\begin{array}{l}\text { Good } \\
\text { Quality- } \\
\text { Level III }\end{array}$ \\
\hline $\begin{array}{l}\text { Joo and Huber } \\
(2014) \text {. An } \\
\text { integrative review } \\
\text { of nurse-led } \\
\text { community-based } \\
\text { case management } \\
\text { effectiveness. }\end{array}$ & $\begin{array}{l}\text { Examine the } \\
\text { effectiveness of } \\
\text { CBCM } \\
\text { programs in } \\
\text { improving } \\
\text { patient } \\
\text { outcomes. }\end{array}$ & $\begin{array}{l}\text { Integrative } \\
\text { review guided by } \\
\text { Whittemore \& } \\
\text { Knafl (2005) } \\
\text { Methodology }\end{array}$ & $\begin{array}{l}18 \text { articles were } \\
\text { selected and } \\
\text { appraised. RN or } \\
\text { NCM led } \\
\text { intervention. } \\
\text { Transitional care } \\
\text { interventions } \\
\text { duration of } 6 \\
\text { weeks to } 4 \text { years. } \\
\text { Chronic disease } \\
\text { patients. }\end{array}$ & $\begin{array}{l}\text { CBCM } \\
\text { decreased } \\
\text { hospital access } \\
\text { outcomes, } \\
\text { especially } \\
\text { readmissions } \\
\text { and increased } \\
\text { cost } \\
\text { effectiveness, } \\
\text { patient outcomes } \\
\text { and satisfaction. }\end{array}$ & $\begin{array}{l}\text { Good } \\
\text { Quality- } \\
\text { Level V }\end{array}$ \\
\hline $\begin{array}{l}\text { Pfaff et al. (2013). } \\
\text { An integrative } \\
\text { review of the } \\
\text { factors influencing } \\
\text { new graduate nurse } \\
\text { engagement in } \\
\text { interprofessional } \\
\text { collaboration. }\end{array}$ & $\begin{array}{l}\text { Evaluation of } \\
\text { the barriers and } \\
\text { facilitators to } \\
\text { new graduate } \\
\text { nurse } \\
\text { engagement in } \\
\text { IP collaboration. }\end{array}$ & $\begin{array}{l}\text { Integrative } \\
\text { review guided by } \\
\text { Whittemore \& } \\
\text { Knafl (2005) } \\
\text { Methodology }\end{array}$ & $\begin{array}{l}26 \text { articles were } \\
\text { selected and } \\
\text { appraised. New } \\
\text { graduate nurse } \\
\text { relationships } \\
\text { focused on IP } \\
\text { collaboration. } \\
\text { North American } \\
\text { care settings. }\end{array}$ & $\begin{array}{l}\text { New graduate } \\
\text { nurse barriers to } \\
\text { IP collaboration } \\
\text { were individual } \\
\text { (self-confidence, } \\
\text { knowledge, } \\
\text { experience, or } \\
\text { communication), } \\
\text { team, and } \\
\text { leadership } \\
\text { factors. }\end{array}$ & $\begin{array}{l}\text { Good } \\
\text { Quality- } \\
\text { Level V }\end{array}$ \\
\hline
\end{tabular}




\begin{tabular}{|c|c|c|c|c|c|}
\hline $\begin{array}{l}\text { Pfaff et al. (2014). } \\
\text { Exploring new } \\
\text { graduate nurse } \\
\text { confidence in } \\
\text { interprofessional } \\
\text { collaboration: A } \\
\text { mixed methods } \\
\text { study. }\end{array}$ & $\begin{array}{l}\text { Explore new } \\
\text { graduate nurse } \\
\text { confidence in IP } \\
\text { collaboration. }\end{array}$ & $\begin{array}{l}\text { Mixed methods, } \\
\text { cross-sectional } \\
\text { descriptive } \\
\text { survey }\end{array}$ & $\begin{array}{l}\text { New graduate } \\
\text { nurses }(n=514) \\
\text { practicing at } \\
\text { acute, } \\
\text { community, and } \\
\text { long-term care } \\
\text { facilities in } \\
\text { Ontario, Canada. }\end{array}$ & $\begin{array}{l}\text { New graduate } \\
\text { nurses reported } \\
\text { increased } \\
\text { confidence were } \\
\text { based on new } \\
\text { graduate nurse } \\
\text { development as } \\
\text { well as team and } \\
\text { leadership } \\
\text { support. }\end{array}$ & $\begin{array}{l}\text { Good } \\
\text { Quality- } \\
\text { Level IIIb }\end{array}$ \\
\hline $\begin{array}{l}\text { Riegel et al. (2017). } \\
\text { Randomized } \\
\text { controlled } \\
\text { trial of telephone } \\
\text { case management } \\
\text { in Hispanics of } \\
\text { Mexican origin } \\
\text { with heart failure. }\end{array}$ & $\begin{array}{l}\text { Validate the } \\
\text { value of } \\
\text { telephonic } \\
\text { transitional CM } \\
\text { in lowering } \\
\text { hospital } \\
\text { admissions, } \\
\text { improving } \\
\text { health-related } \\
\text { quality of life } \\
\text { (HRQL), and } \\
\text { despair in HF } \\
\text { Hispanic } \\
\text { patients. }\end{array}$ & $\begin{array}{l}\text { Quantitative- } \\
\text { Experimental/ } \\
\text { RCT }\end{array}$ & $\begin{array}{l}\text { Hispanic HF } \\
\text { inpatients ( } n= \\
\text { 134) were } \\
\text { enrolled from a } \\
\text { two Southern } \\
\text { California } \\
\text { Hospitals and } \\
\text { randomized to } \\
\text { receive } \\
\text { telephonic care } \\
\text { intervention ( } n= \\
69) \text { or routine } \\
\text { care (n = 65). } \\
\text { Mexican decent. } \\
\text { Elderly adults: } \\
65 \text { years old or } \\
\text { older. Men or } \\
\text { Women. English } \\
\text { or Spanish- } \\
\text { speaking. Acute } \\
\text { care. }\end{array}$ & $\begin{array}{l}\text { No significant } \\
\text { group } \\
\text { differences were } \\
\text { found in HF } \\
\text { readmissions } \\
\text { (usual care: } 0.49 \\
\pm 0.81 \text { [CI } 0.25- \\
0.73] \text {; } \\
\text { intervention: } \\
0.55 \pm 1.1 \text { [CL } \\
0.32-0.78] \text { at } 6 \\
\text { months). No } \\
\text { group } \\
\text { differences were } \\
\text { found in } \\
\text { readmission } \\
\text { rates, hospital } \\
\text { days, costs, } \\
\text { mortality, } \\
\text { HRQL, or } \\
\text { depression. } \\
\text { Telephonic } \\
\text { transitional CM } \\
\text { was not } \\
\text { adequate to } \\
\text { improve patient } \\
\text { outcomes in HF } \\
\text { Hispanic } \\
\text { patients. }\end{array}$ & $\begin{array}{l}\text { Good } \\
\text { Quality- } \\
\text { Level I }\end{array}$ \\
\hline $\begin{array}{l}\text { Riegel et al. (2002). } \\
\text { Effect of a } \\
\text { standardized nurse } \\
\text { case-management } \\
\text { telephone } \\
\text { intervention on } \\
\text { resource use in } \\
\text { patients with } \\
\text { chronic heart } \\
\text { failure. }\end{array}$ & $\begin{array}{l}\text { Assess the } \\
\text { effectiveness of } \\
\text { telephonic } \\
\text { transitional CM } \\
\text { intervention on } \\
\text { resource use in } \\
\text { chronic HF } \\
\text { patients. }\end{array}$ & $\begin{array}{l}\text { Quantitative, } \\
\text { RCT }\end{array}$ & $\begin{array}{l}\text { Patients ( } n= \\
358) \text { from two } \\
\text { Southern } \\
\text { California } \\
\text { Hospitals } \\
\text { assigned to } \\
\text { receive six } \\
\text { months of } \\
\text { telephonic care } \\
\text { intervention ( } n= \\
\text { 130) or routine } \\
\text { care ( } n=228) \\
\text { based on the } \\
\text { group their } \\
\text { provider was } \\
\text { randomized. HF } \\
\text { diagnosed }\end{array}$ & $\begin{array}{l}\text { HF } \\
\text { hospitalization } \\
\text { rate was lower } \\
\text { in the } \\
\text { intervention } \\
\text { group at } 3 \\
\text { months ( } 45.7 \% \text {, } \\
p=.03 \text { ) and } 6 \\
\text { months ( } 47.8 \%, \\
p=.01), \\
\text { hospital days ( } p \\
=.03), \text { multiple } \\
\text { readmissions ( } p \\
=.03), \text { and costs } \\
\text { (45.5 } \%, p= \\
.04) . \text { Increase in } \\
\text { patient }\end{array}$ & $\begin{array}{l}\text { Good } \\
\text { Quality- } \\
\text { Level I }\end{array}$ \\
\hline
\end{tabular}




\begin{tabular}{|c|c|c|c|c|c|}
\hline & & & $\begin{array}{l}\text { patients. } \\
\text { Practicing } \\
\text { Cardiology or } \\
\text { Internal } \\
\text { Medicine } \\
\text { Physician. Acute } \\
\text { care. }\end{array}$ & $\begin{array}{l}\text { satisfaction in } \\
\text { the intervention } \\
\text { group. }\end{array}$ & \\
\hline $\begin{array}{l}\text { Thoma and Waite } \\
\text { (2018). } \\
\text { Experiences of } \\
\text { nurse case } \\
\text { managers within a } \\
\text { central discharge } \\
\text { planning role of } \\
\text { collaboration } \\
\text { between } \\
\text { physicians, patients } \\
\text { and } \\
\text { other healthcare } \\
\text { professionals: A } \\
\text { sociocultural } \\
\text { qualitative study. }\end{array}$ & $\begin{array}{l}\text { Examine NCM } \\
\text { experiences } \\
\text { within an acute } \\
\text { care } \\
\text { international } \\
\text { healthcare } \\
\text { system on early } \\
\text { collaboration } \\
\text { with } \\
\text { multidiscipli- } \\
\text { nary team on } \\
\text { discharge } \\
\text { planning. }\end{array}$ & $\begin{array}{l}\text { Qualitative, } \\
\text { descriptive. }\end{array}$ & $\begin{array}{l}\text { NCMs }(n=8) \\
\text { who practiced in } \\
\text { a German } \\
\text { teaching } \\
\text { hospital. Seven } \\
\text { women } \\
\text { participants and } \\
\text { one male } \\
\text { participant. } \\
\text { Ages 30-45. }\end{array}$ & $\begin{array}{l}\text { Patient advocacy } \\
\text { is important for } \\
\text { effective } \\
\text { collaboration } \\
\text { between NCM, } \\
\text { patient, and care } \\
\text { team to establish } \\
\text { a safe discharge } \\
\text { plan. Significant } \\
\text { themes that } \\
\text { emerged were } \\
\text { professional } \\
\text { competency of } \\
\text { the NCM as } \\
\text { self-valued or } \\
\text { valued by peers, } \\
\text { shared } \\
\text { collaboration } \\
\text { between CM } \\
\text { and patients as } \\
\text { well as } \\
\text { identification of } \\
\text { Barriers to } \\
\text { Discharge } \\
\text { (BTD). }\end{array}$ & $\begin{array}{l}\text { Good } \\
\text { Quality- } \\
\text { Level III }\end{array}$ \\
\hline
\end{tabular}

